\title{
B Cell Immunophenotyping and Expression Analysis of B Cell Specific Molecules of Patients with Benign Multiple Sclerosis
}

\author{
Benign MS Hastalarinin B Hücre İmmünfenotiplemesi ve B Hücresine Özgü \\ Moleküllerin Ekspresyon Analizi
}

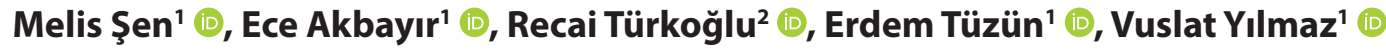 \\ 'Department of Neuroscience, İstanbul University Aziz Sancar Institute of Experimental Medicine, İstanbul, Turkey \\ ${ }^{2}$ Department of Neurology, Haydarpasa Numune Training and Research Hospital, İstanbul, Turkey
}

Cite this article as: Şen M, Akbayır E, Türkoğlu R, Tüzün E, Yılmaz V. B Cell Immunophenotyping and Expression Analysis of B Cell Specific Molecules of Patients with Benign Multiple Sclerosis. Experimed 2019; 9(3): 105-12.

\begin{abstract}
Objective: Multiple Sclerosis (MS) is a progresive and an immune mediated inflammatory central nervous disease. The focus of this study was to determine the possible relationship between B cell immunophenotypes and related gene expressions in the benign MS (BMS) group with disease and cognitive processes.
\end{abstract}

Material and Method: Twenty BMS patients, 16 non-BMS and 28 healthy volunteers were included in the study. Gene expression was performed by real-time PCR (RT-PCR). Immunophenotyping of peripheral $B$ cells was also evaluated by flow cytometry. The relationship between cognitive functions and gene expression levels and $B$ cell subtypes was investigated.

Results: It was observed that naïve $\left(C^{2} 19^{+} \lg D^{+} C D 27^{-}\right)$cells were higher in the BMS group compared to the healthy group (HC), and memory B cells showed opposite changes. Un-switched memory $B$ cells $\left(C D 19^{+} \operatorname{lgD}{ }^{+} C D 27^{+}\right)$were found to be higher in the benign group than in the $\mathrm{HC}$. The expression of BANK and BLNK was found to be lower in both MS groups than in the HC. As a result of neuropsychological examinations and cognitive tests; it was observed that motor processes in BMS were better protected than Non-BMS.

Conclusion: These findings support that B cell functions may have molecular and cellular effects, and may lead to regression in inflammation and clinical progression. Molecules showing significant changes in our study may play a role as prognostic biomarkers in MS.

Keywords: Benign Multiple Sclerosis, B cell, immunophenotyping, gene expression

\section{öz}

Amaç: Multipl Skleroz (MS), aksonal dejenerasyona, demiyelinizasyona ve inflamasyona bağlı gelişen, merkezi sinir sistemini etkileyen progresif bir hastalıktır. Bu çalışmada benign MS (BMS) grubunda periferik kan $B$ hücre immünofenotiplerinin ve $B$ hücresi ile ilişkili gen ekspresyonlarının hastalık ve bilişsel süreçlerle ilişkisinin araştırılması hedeflenmiştir.

Gereç ve Yöntem: Yirmi BMS hastası, 16 benign olmayan MS (NonBMS) hastası ve 28 sağlıklı gönüllü çalışmaya dahil edildi. Daha önce periferik kan hücrelerinde yapılan gen mikroarray çalışması ile gruplar arasında ekspresyonu değişikliği gözlenen genlerin validasyonu gerçek zamanlı PZR ile yapıldı. Periferik B hücrelerinin immünofenotiplemesi akım sitometrisi ile değerlendirildi. Bilişsel fonksiyonlar ile gen ekspresyon seviyeleri ve $B$ hücre alttipleri arasındaki olası ilişki araştırıldı.

Bulgular: Naif (CD19+ $\left.\lg \mathrm{D}^{+} \mathrm{CD} 27^{-}\right)$B hücrelerinin BMS grubunda sağlıklılara göre yüksek olduğu, hafıza $B$ hücrelerinin zıt yönde değişiklik gösterdiği gözlendi. Dönüşmemiş hafıza $B$ hücrelerinin $\left(C D 19^{+} \operatorname{lgD}{ }^{+} C D 27^{+}\right)$ise benign grupta sağlıklılara göre yüksek olduğu belirlendi. BANK ve BLNK gen ekspresyonları her iki MS grubunda da sağlıklılardan düşük olarak belirlendi. Nöropsikolojik incelemeler ve kognitif testler sonucunda, BMS'te motor süreçlerin Non-BMS'ye göre korunduğu gözlendi.

Sonuç: Bu bulgular B hücresi işlevlerinin moleküler ve hücresel etkileri olabileceği ve inflamasyon ile klinik progresyonda gerilemeye yol açabileceği yönündeki görüşleri desteklemektedir. Değişiklik gösteren moleküllerin MS hastalığında prognostik biyobelirteç olarak rol oynaması da mümkündür.

Anahtar Kelimeler: Benign Multipl Skleroz, B hücresi, immünfenotipleme, gen ekspresyonu 


\section{INTRODUCTION}

Multiple sclerosis (MS) is a multifactorial chronic demyelinating disease that affects the patient's quality of life, and the exact cause of disease is unknown. It is a disease characterized by repetitive demyelination in the central nervous system (CNS), with autoimmunity in the pathophysiology (1). Although the pathogenesis of MS is not fully known, migration of autoreactive lymphocytes through the blood brain barrier into the CNS is thought to initiate the inflammation process (2). Clinical subtypes of MS; attacks (RRMS), primary progressive (PPMS), secondary progressive (SPMS), progressive-recurrent and benign MS (BMS) are classified as (3). BMS is a retrospective diagnosis characterized by low lesion burden on MRl, which is characterized by rare attacks without serious sequelae. Patients with EDSS scores $\leq 3-15$ years after the onset of the disease are considered BMS $(3,4)$. Although a relatively slow progression is observed in the somatic neurological findings of BMS patients, other nervous system functions may be severely impaired (5).

T lymphocytes have played a major role in MS immunopathogenesis until recently. Autoreactive T lymphocytes and antibodies that develop against CNS elements in MS cases play a role in the formation of tissue lesion and inflammation, and $\mathrm{T}$ lymphocytes react to myelin by causing demyelination $(6,7)$. However, recent studies also have shown the importance of $B$ cells in the pathogenesis of MS. There is evidence that B cells have different effects other than antibody production, such as antigen uptake and presentation, stimulation of T lymphocytes, cytokine, chemokine and neurotropic factors. Treatment approaches for the removal of antibodies from the circulation leads to improvement in MS, and is an indication that B cells play an active role in the pathogenesis of the disease (7). The fact that monoclonal antibody-based treatment methods targeting $B$ cells are effective in stopping the progression of the disease suggested that $B$ cells also play a role in the development of disability $(8,9)$.

Cognitive impairment is frequently seen in MS and affects 70\% of patients. Cognitive functions are affected in the late and early stages of the disease (including clinically isolated syndrome), and impairments in the course of the disease may occur. There are many studies showing that cognitive findings deteriorate in BMS cases (5).

The aim of our study was to evaluate the role of peripheral blood B cells in the BMS group, which had not previously been studied in the literature. Immunophenotyping of B cells and their subgroups (plasma, plasmablast, naïve, memory and regulatory), and expression of genes associated with B cells, are aimed to determine the possible relationship with cognitive processes. In light of this information, the goal of this research was to determine the importance of B-cell immunophenotyping in BMS and the importance of B-cell-related genes in expression analysis, and the possible relationship of MS subgroups to cognitive processes.

\section{MATERIAL AND METHOD}

\section{Study Groups}

A total of 36 multiple sclerosis patients (BMS, $n=20$ and non-Benign MS (Non-BMS), $n=16$ ), who were followed up from the Multiple Sclerosis Outpatient Clinic of Neurology Department of Istanbul Medical Faculty, and age/sex-matched healthy individuals as the control group $(n=28)$ were included in the study. All procedures performed in studies involving human participants were in accordance with the ethical standards of Istanbul University, İstanbul School of Medicine, Clinical Research Ethical Committee (Project Number 2018/449). Participants were selected from patients who were over 18 years of age, diagnosed according to the revised McDonald criteria for 2017, and had no attacks in the last three months, and the healthy control group was selected from participants who were over 18 years of age, had no neurological and autoimmune disorders, had no infectious diseases in the last 3 months, and had not used immunosuppressive drugs (Table 1).

\section{Isolation of Peripheral Blood Mononuclear Cells}

Peripheral blood mononuclear cells (PBMC) were isolated using the gradient method. For this purpose, donor blood collected in EDTA containing tubes was diluted with the same volume of phosphate buffered saline (PBS) and added slowly to Ficoll (Lympho-paque). Tubes were centrifuged at $3000 \mathrm{rpm}$ for 20 minutes at $20^{\circ} \mathrm{C}$ with brake. In the resulting cell gradient, the mononuclear cell layer was collected, centrifuged at $1800 \mathrm{rpm}$ for 10 minutes at $4^{\circ} \mathrm{C}$ by adding the same volume of PBS and the supernatant was removed. The viability of the cells was determined by trypan blue and freezed in $-80^{\circ} \mathrm{C}$ with $1 \times 10^{6}$ cells in fetal bovine serum (FBS) with 10\% Dimethyl sulfoxide (DMSO).

\section{Immunophenotyping}

Frozen cells were dissolved in a water bath that sets at $37^{\circ} \mathrm{C}$ and centrifuged in medium (RPMI 1640 and 10\% FBS) at $1800 \mathrm{rpm}$ at + $4^{\circ} \mathrm{C}$ for 10 minutes. Then, cells were stained with anti-human monoclonal CD19-APC, CD24-PerCP, IgD-APC/Cy7, CD138-PE, CD27-FITC, and CD38-Alexa fluor 700 (Biolegend) conjugates for $30 \mathrm{~min}$ at 4 ${ }^{\circ} \mathrm{C}$, then, washed with PBS and resuspended in PBS. Immunofluorescence staining was performed (BD FACS Aria II), and data were analyzed using the FlowJo software.

\section{RNA Isolation and Determinating Target Genes}

For identification of candidate genes, a microarray assay was performed. RNA expression profiles obtained from PBMCs of 16 participants, 5 RRMS, 6 BMS and 5 healthy control groups, were determined with the Sureprint G3 Human Gene Expression V3 microarray (MA) system. In this context, a total of 26083 Entrez genes were evaluated, and microarray analysis determined the target genes that showed changes between the groups.

In order to do validation of these candidate genes, RNA isolation from PBMC was performed according to the instructions of the QIAGEN RNeasy Mini kit (Hilden, Germany). The quality and quantity of the obtained RNA were evaluated spectrophotometrically. For the purity of RNA, the OD value at $260 \mathrm{~nm} / 280$ $\mathrm{nm}$ between 1.9 and 2.1 were included in the study. 
Table 1. Clinical and demographic data

\begin{tabular}{lcccc}
\hline & BMS $(\mathbf{n}=\mathbf{2 0})$ & Non-BMS $(\mathbf{n}=\mathbf{1 6})$ & Healthy Control $(\mathbf{n}=\mathbf{2 8})$ & $\mathbf{p}$ \\
\hline Sex (F/M) & $17 / 3$ & $10 / 6$ & $18 / 10$ & 0.221 \\
\hline Age (years) & $40.5 \pm 9.54$ & $47.1 \pm 8.4$ & $39.3 \pm 8.7$ & 0.024 \\
\hline Age at disease onset (years) & $25.3 \pm 8.39$ & $32.4 \pm 9.36$ & 0.022 \\
\hline Disease duration (years) & $13.5 \pm 4.35$ & $14.1 \pm 4.12$ & 0.69 \\
\hline EDSS score & $2.42 \pm 0.52$ & $5.1 \pm 0.95$ & $<0.0001$ \\
\hline Total Attack Scores & $7.75 \pm 4.33$ & $7.3 \pm 4.25$ & 0.76 \\
\hline
\end{tabular}

Table 2. RT-PCR programme

\begin{tabular}{lccc}
\hline Program & $\begin{array}{c}\text { Temperature } \\
\left({ }^{\circ} \mathbf{C}\right)\end{array}$ & $\begin{array}{c}\text { Time } \\
(\mathbf{h}: \text { min:sec) }\end{array}$ & Cycle \\
\hline Pre-incubation & 95 & $00: 08: 00$ & 1 \\
\hline Amplification & 95 & $00: 00: 15$ & 40 \\
\hline & 55 & $00: 00: 05$ & \\
\hline & 72 & $00: 00: 10$ & \\
\hline Melting Curve & 95 & $00: 00: 05$ & 1 \\
\hline & 65 & $00: 01: 00$ & 1 \\
\hline & 97 & Continuous & 1 \\
\hline Cooling & 4 & $00: 00: 20$ & 1 \\
\hline
\end{tabular}

\section{Synthesis of CDNA and real-time PCR Studies}

cDNA synthesis was carried out with the Transcriptor First Strand cDNA Synthesis Kit (Basel, Switzerland), according to the manufacturer's instructions. All samples were prepared with 10 $\mathrm{ng} /$ del CDNA in the tubes. real-time PCR (RT-PCR) reactions were performed on the LightCycler 480 instrument, and following the instructions of the Fast Start DNA Master SYBR Green I kit (Roche, Basel, Switzerland). Gene-specific reverse and forward primers were used at a concentration of $600-800 \mathrm{nM}$. For CDNAs, the glyceraldehyde 3-phosphate dehydrogenase (GAPDH) gene, which is expressed in equal amounts in each tissue and responsible for basic cellular functions (house-keeping gene, reference gene), was used. cDNA samples 100 ng and forward / reverse primers (Table 2) 600-800 nM were used and the program in Table 3 was applied. Amplification curves and melting peaks were evaluated after the procedure.

\section{Cognitive Tests}

Based on the literature findings, a test battery has been created for attention, memory, processing speed and executive function areas, which are reported to be the most impaired in MS. The neuropsychological tests to be performed accordingly are Rey auditory and verbal learning, number index, WAIS-R's password subtest, verbal fluency, Wisconsin card matching and Stroop tests. The cognitive tests applied in the study are shown in Table 4.
Table 3. Target genes and primers

\begin{tabular}{ll}
\hline Gene & Primer Sequence \\
\hline BLK_Frw & TAGATCACAGGGTCG-GAAGG \\
\hline BLK_Rev & GGCAGCGGATCTTATAGTGC \\
\hline TGFB1_Frw & GTACCTGAACCCGTGTTGCT \\
\hline TGFB1_Rev & CAACTCCGGTGACATCAAAA \\
\hline ATP1B3_Frw & CAGTCTGTCCTGATGGAGCA \\
\hline ATP1B3_Rev & TGGCACTCCTTCAGGCTTTA \\
\hline BANK1_Frw & GTTCAGACCCCGCACATATT \\
\hline BANK1_Rev & CCTTCCCCTTCCATTTCATT \\
\hline BLNK_Frw & GAGCAGTGGTCCGATGACTT \\
\hline BLNK_Rev & TGGGCTTACTGGGAAGTGTC \\
\hline FCRL2_Frw & CTCTGGGGACTGTTTGGTGT \\
\hline FCRL2_Rev & GGTTGGGCTTGAATAGGTGA \\
\hline SWAP70_Frw & CGGTGCTGAAGGTTCCTCAT \\
\hline SWAP70_Rev & GACACAGAGGGTCCAACACA \\
\hline CCL19_Frw & CCTGCTGGTTCTCTGGACTT \\
\hline CCL19_Rev & TTGACGACACTACAG-CAGGCAC \\
\hline GAPDH_Frw & \\
\hline GAPDH_Rev & CATGACCCCTTCATT \\
\hline GWCCATGGAATTT \\
\hline
\end{tabular}

\section{Statistical Analysis}

ANOVA test was used for parametric data, to compare the clinical and demographic characteristics of the patients and healthy control subjects, and paired comparisons between the disease subgroups were performed by the Student t-test or Mann-Whitney $U$ test. Nonparametric data were compared with the chi-square test. Flow cytometry and RT-PCR results were compared with ANOVA and Tukey's post-hoc test in cases with more than two groups, and Student's t-test in cases with more than two groups. Relative quantification of target genes 
was performed by $2-\Delta \Delta C T$ method using the glyceraldehyde 3-phosphate dehydrogenase (GAPDH) as the reference gene. Pearson correlation test was used for correlation analysis, statistical significance was defined as $p$ value less than 0.05 , and a analysis was performed using the SPSS 21.0 program. The GraphPad Prism 5 program was used for the graphs.

\section{RESULTS}

\section{Clinical and Demographic Features}

The age, onset age, duration of disease, EDSS and number of attacks of the BMS, Non-BMS MS and healthy control subjects were compared. BMS patients' age, disease onset age and EDSS scores were significantly lower than respectively Non-BMS patients $(p=0.002, p=0.022$ and $p<0.0001)$. Duration of disease and total number of attacks were not different between the

Table 4. Cognitive tests

\begin{tabular}{ll}
\hline Cognitive Test & $\begin{array}{l}\text { Related to Cognitive } \\
\text { Process }\end{array}$ \\
\hline Selective Reminding Test (Srttl) & Verbal Memory Acquisition \\
\hline Spatial Recall Test (Sparttl) & Visual Memory Acquisition \\
\hline $\begin{array}{l}\text { Sustained Attention and Speed } \\
\text { of Information Processing }\end{array}$ & Executive Functions \\
\hline $\begin{array}{l}\text { Symbol Digit Modalities Test } \\
\text { (SDMT) }\end{array}$ & Executive Functions \\
\hline $\begin{array}{l}\text { Controlled Oral Word } \\
\text { Association Test (COWAT) }\end{array}$ & Executive Functions \\
\hline 9-Hole Peg Test & Motor Functions \\
\hline Timed 25-Foot Walk Test & Motor Functions \\
\hline Beck Test & Depression \\
\hline
\end{tabular}

groups $(p=0.69$ and $p=0.76)$. All MS cases included in the study were under an immunomodulatory treatment (inferferon-beta, glatiramer acetate or fingolimod) (Table 1).

\section{Comparison of Peripheral Blood Mononuclear Cell Phenotypes}

Distribution of Peripheral Blood B, T and Natural Killer Cells Peripheral blood mononuclear cell (PBMC) groups of 20 BMS and 16 Non-BMS cases and 28 healthy control donors were evaluated. When the PBMCs of all the subjects were evaluated; the percentage of CD19 expressing B cells was not found to be different between the groups, but $C D 3^{+} T$ cell $(p=0.0019)$

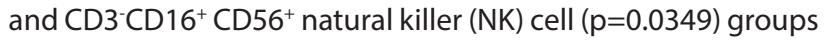
were found to be different. $C D 3^{+} T$ cells were significantly lower in both the BMS group $(p<0.01)$ and the Non-BMS group $(p<0.05)$ compared to healthy subjects. When NK cells were evaluated, it was determinated that these cells were significantly higher in the Non-BMS group than in the healthy ones $(p<0.05)$ (Figure 1).

\section{Distribution of Peripheral Blood B Cell Immunophenotypes Between Groups}

In immature (CD19+' IgD-CD27) subgroup of immature $B$ cells that did not encounter antigen, there was no difference between the study groups, whereas the percentage of naive $\left(C_{19}{ }^{+} \operatorname{lgD}{ }^{+} \mathrm{CD}_{27}\right)$ cells was higher in the BMS group compared to healthy subjects $(p<0.05)$. In contrast, memory B cells showed significant changes in the opposite direction. Unswitched memory $B$ cells $\left(C D 19^{+} \operatorname{lgD}{ }^{+} C D 27^{+}\right)$were found to be higher in the benign group than in healthy subjects $(p<0.01)$. The switched $\left(C D 19^{+} \operatorname{lgD}-C D 27^{+}\right)(p=0.05)$ memory B cells were found to be lower in both patient groups compared to healthy subjects $(p<0.05)$. However, there was no difference between the MS subgroups. Plasmablasts $\left(\mathrm{CD} 19^{+} \mathrm{CD} 38^{++} \mathrm{CD} 138^{-}\right)$, which are antibody-producing B cell precursors, had similar percentages in the groups. However, it was observed that antibody-producing $\mathrm{B}$ cells, plasma cells $\left(\mathrm{CD} 19^{+} \mathrm{CD} 38^{+} \mathrm{CD} 138^{+}\right)$

Table 5. Distribution of cognitive tests in disease groups

\begin{tabular}{|c|c|c|c|c|c|c|c|}
\hline & BMS $(n=20)$ & $\begin{array}{c}\text { Non-BMS } \\
(n=16)\end{array}$ & $\begin{array}{l}\text { Healty } \\
\text { Control } \\
(n=28)\end{array}$ & ANOVA $p$ & $\begin{array}{c}\text { p value } \\
\text { (BMS vs. } \\
\text { non-BMS) }\end{array}$ & $\begin{array}{c}\text { p value } \\
\text { (BMS vs. } \\
\text { HC) }\end{array}$ & $\begin{array}{c}\text { p value } \\
\text { (non-BMS } \\
\text { vs. HC) }\end{array}$ \\
\hline Verbal Memory Test & $8.1 \pm 1.5$ & $7.1 \pm 1.61$ & $9.2 \pm 1.3$ & $<0.0001$ & & $<0.05$ & $<0.001$ \\
\hline Visual Memory Test & $4.7 \pm 1.83$ & $4 \pm 1.68$ & $6.2 \pm 1.5$ & $<0.0001$ & & $<0.01$ & $<0.001$ \\
\hline PASAT Test & $38.4 \pm 13.2$ & $33.3 \pm 11.7$ & $48.68 \pm 7.67$ & $<0.0001$ & & $<0.01$ & $<0.001$ \\
\hline SDMT Test & $37.5 \pm 14.7$ & $27.1 \pm 11.8$ & $53.6 \pm 19.27$ & $<0.0001$ & & $<0.01$ & $<0.001$ \\
\hline 9-Hole PegTest & $20.8 \pm 2.63$ & $30 \pm 6.19$ & $18.63 \pm 2.15$ & $<0.0001$ & $<0.001$ & & $<0.001$ \\
\hline Timed 25-Foot Walk Test & $6.81 \pm 1.13$ & $15.13 \pm 7.94$ & $6.1 \pm 1.48$ & $<0.0001$ & $<0.001$ & & $<0.001$ \\
\hline COWAT Test & $55.9 \pm 20.19$ & $45 \pm 22.96$ & $75.6 \pm 17.48$ & $<0.0001$ & & $<0.01$ & $<0.001$ \\
\hline Stroop Test & $56.95 \pm 31.9$ & $68.15 \pm 32.82$ & $36.8 \pm 14.7$ & 0.0002 & & $<0.05$ & $<0.001$ \\
\hline Beck Test & $13.55 \pm 7.69$ & $13.57 \pm 7.67$ & $7 \pm 5.72$ & 0.0005 & & $<0.01$ & $<0.01$ \\
\hline
\end{tabular}


tended to be lower in the BMS group than in the non-benign group. In the regulatory $B$ cells (Breg, CD $19^{+} \mathrm{CD} 24^{++} \mathrm{CD} 38^{++}$) which had the feature of immune suppressor cells, a significant increase was detected in the BMS group compared to healthy subjects $(p<0.05)$ (Figure 2$)$.
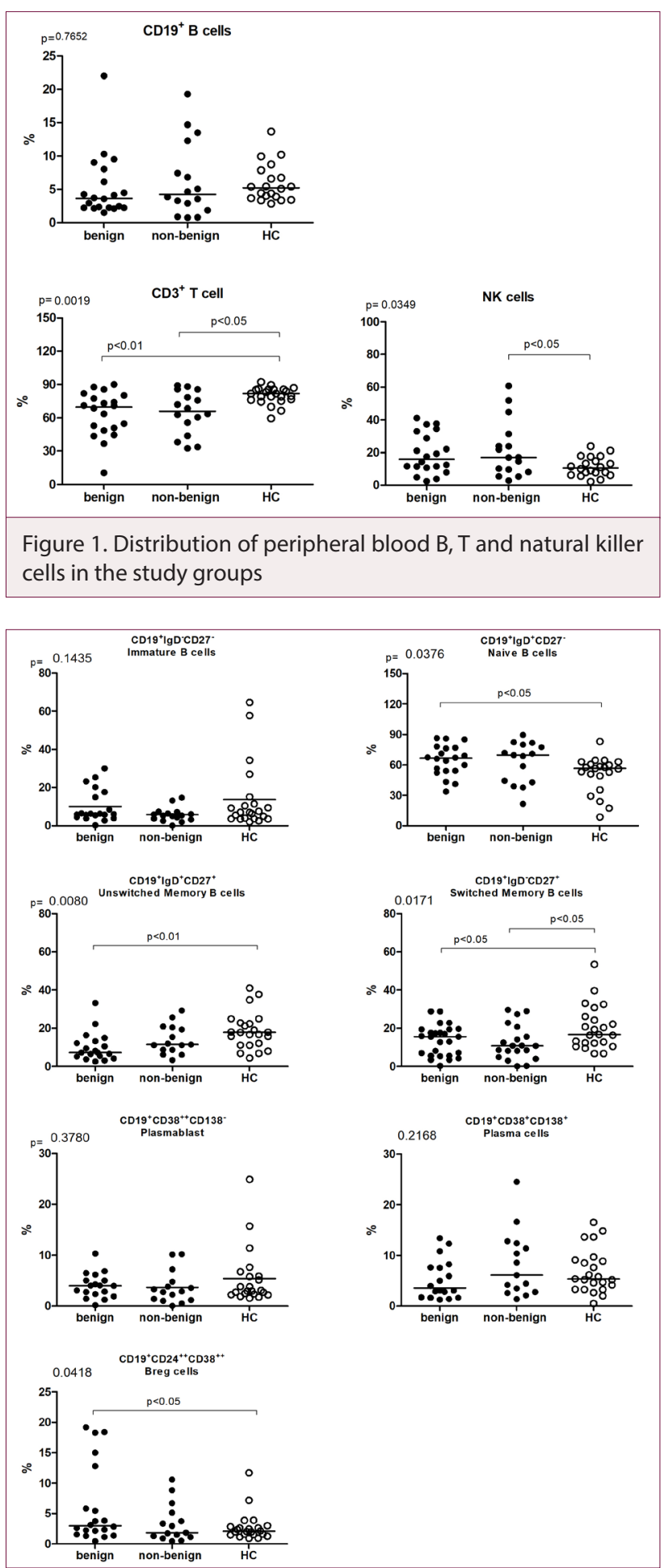

Figure 2. Distribution of peripheral blood B cell immunophenotypes in the study groups

\section{Validation of Genes by RT-PCR}

Quantitative PCR primers were designed to validate the expression patterns of target genes determined by microarray data analysis in PBMCs of the study group. First, the sequences of the target genes were reached from http://www.ncbi.nlm. nih.gov/gene, and then, the appropriate primer sequences were designed with the help of http://www.bioinformatics. $\mathrm{nl} /$ cgi-bin/primer3plus/primer3plus.cgi (Table 2). Cases with sufficient RNA samples (13 BMS and 12 non-BMS, 10 healthy control) were studied in duplicate for all genes.

Expression analysis of the TGFB1, BANK1, BLNK, FCRL2, CCL19 and BLK genes related to $B$ cell subtypes and ATP1B3, SWAP70 genes related to both $T$ and $B$ cell subtypes were performed. Expression of BLK $(p<0.05)$, TGFB $(p<0.05)$ and FCRL $(p<0.01)$ genes was significantly lower in non-benign MS patients than in healthy subjects. However, expression of KCNS was found significantly higher in the non-BMS group. In the BANK and BLNK genes $(p<0.01$ and $p<0.05$, respectively), significantly lower expression was detected in both MS groups than in healthy subjects (Figure 3).

In particular, its association with B cell functions as a candidate gene supports B cell contribution in the pathogenesis of MS. The genes that have changed as a result of microarray analysis are as follows: BLK (Proto-Oncogene, Src Family Tyrosine Kinase) triggers $B$ cell activation signal after the antigen interacts with the $B$ cell. TGFB is produced by Breg cells and has supressive effects. BANK1 (B Cell Scaffold Protein with Ankyrin Repeats) provides the mobilization of calcium from the stores during $B$ cell receptor interaction. KCNS (Potassium Voltage-Gated Channel Modifier Subfamily S Member 1) are associated with the regulation of the resting membrane potential and the control of the shape and frequency of action potentials. FCRL2 (Fc Receptor Like A 2) mediate the destruction of lgG-coated antigens and of cells induced by antibodies.

There was no correlation between gene expression levels and demographic data, B cell subtype rates and gene expression

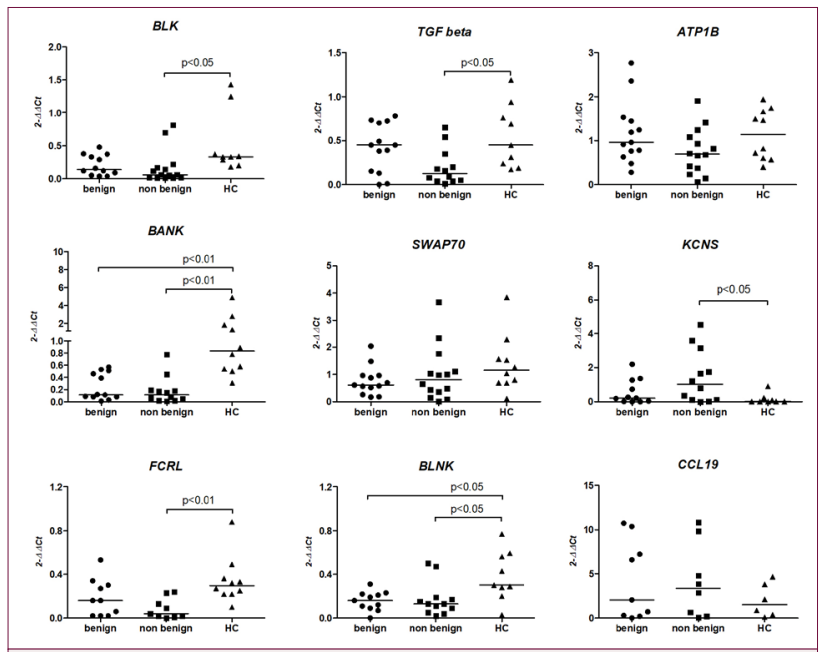

Figure 3. Distribution of gene expression in the study groups 
levels, but inverse correlations were determined between BANK 1 and executive functions tests (respectively $p=0,028 R=-$ $0,439$ ve $p=0,0086 R=-0,51)$.

\section{Cognitive Analysis}

As a result of neuropsychological examinations and cognitive tests; motor processes in BMS patients were better preserved than in non-BMS. When the cognitive parameters were evaluated, it was found that BMS cases showed the worse performance in all cognitive functions compared to healthy subjects and no significant difference was found in non-BMS BMS comparisons. Beck depression inventory scores were also significantly lower in the benign and non-BMS groups compared to the healthy group (Table 5).

\section{DISCUSSION}

Multiple sclerosis is an autoimmune, progressive disease of the CNS with progressive demyelination, inflammation and axonal degeneration (1). In the later stages of the disease, lesions developing due to demyelination in CNS are spread to certain regions of the optic nerves, brain stem, cerebellum and white matter (12). These highly complex etiologic factors of MS (such as autoimmunity, genetic factors, infectious agents, vitamin D, smoking, stress, sleeplessness, drug use) may also vary with age, gender, and ethnicity (13).

The discovery of the key role of B cells in recent years, and the fact that these cells are involved in autoimmune diseases such as MS, also supports the relationship between MS and the interaction with T cells (14). In addition, antibody-producing plasma cells and anti-neuronal antibodies have been reported to play an important role, but B cells with antigen uptake and presentation, stimulation of $\mathrm{T}$ lymphocytes and cytokine production have been reported to be effective in the pathogenesis of the disease (6).

In MS, plasmablasts pass to the periphery and migrate to inflamed brain tissue. In this case, plasmablast and plasma cell production in lymphoid tissue is increased or memory cells in brain tissue start to produce pathogenic antibodies (6). Therefore, the most common B cell subtype found in MS plaques is a long-lasting plasma cell $(11,15)$. The fact that monoclonal antibody-based treatment methods targeting B cells are effective in stopping the progression of the disease suggested that $B$ cells also play a role in the development of disability $(8,9)$.

In this study, benign MS cases considered to be a good prognostic type of MS because of their low disability despite long disease duration were studied. The data obtained from these cases were compared with those of patients with a higher disability level during the same disease period. The main goal of the study was to determine the importance of B-cell immunophenotyping in BMS patients, and the importance of B-cell-related genes in the expression analysis, and the possible relationship of MS subgroups to cognitive processes.
As a result of immunophenotyping studies, unswitched and switched memory cells of effector B cells, which have an important role in the pathogenesis of autoimmune diseases due to their pro-inflammatory properties, were suppressed in MS groups. Among these, unswitched memory B cells were lower in BMS patients than in non-benign ones. Plasma cells, another effector B cell group, likewise tended to be low in BMS cases. Regulatory B lymphocytes with immunosuppressive properties were significantly higher in the BMS group compared to the other study groups. These findings suggest that one of the factors that may cause MS to remain at a low level of disability over a long period of illness may be the change in inflammatory memory $B$ and anti-inflammatory regulatory B cell ratios.

In a previous microarray study, it was shown that suppression of the RNA-polymerase 1 pathway, which is associated with cell survival in BMS cases, causes the effector lymphocytes to easily develop apoptosis and have a short survival (10). This study showed that mechanisms controlling B cell activity suppress MS progression, thus identifying a mechanism that has not been previously described in the literature. Consistent with the results of our study, another study found that the risk of developing MS was low in patients with clinically isolated syndrome with low memory B lymphocyte ratios in peripheral blood (16). Thus, B cell subtypes have been shown to play a role in preventing the progression of the disease in both early and advanced stages of MS. As an important finding, suppression of T cells and some $B$ cell subtypes was found in benign and non-BMS cases compared to healthy subjects. It is possible that this finding is due to the effect of immunomodulatory therapy, and suppression of memory B cells may be a treatment side effect. In this case, the higher level of suppression of memory B cells observed in BMS may be due to the stronger and more effective response of immunomodulatory therapy to this MS subtype.

There was no significant difference between the groups in RTPCR analysis due to the low number of cases. However, similar to phenotyping studies, anti-inflammatory TGF $\beta$ levels were found to be higher in benign MS cases. In addition, disability levels of patients with high TGF $\beta$ levels were found to be low. TGF $\beta$ is a well-known cytokine with anti-inflammatory effects in the pathogenesis of MS. In both MS cases and animal models of MS, a relationship was found between TGF $\beta$ and disability levels. The association of this cytokine with regulatory $B$ lymphocyte levels is also known $(17,18)$. However, there are no studies on the effect of TGF $\beta$ in BMS. It is possible that the high regulatory $B$ percentage in $B M S$ is one of the factors that determine low memory $B$ cell ratios.

Verbal response test results were found to be high in cases with no expression level change between benign and non-BMS cases, and low levels of expression of BANK1 gene (11) which had an effect on $B$ lymphocyte proliferation. The association of this factor with B cell functions is well known, but there are no studies showing its association with MS. It will be appropriate to test expression levels of all the genes studied with a higher 
number of cases and to determine whether these factors may be a predictor of MS prognosis.

Another interesting feature of our study is related to cognitive tests. It was shown that somatic neurological findings (motor, sensory, vision, balance) are preserved in BMS, but cognitive and limbic networks are affected and therefore, the definition of BMS is a deceptive diagnosis. In addition, the lack of correlation between $B$ cell subtype rates and $B$ cell gene expression levels and cognitive test scores suggests that $B$ cells play a role mostly in the progression of physical disability, but different factors are effective in the progression of cognitive findings.

The use of total peripheral blood mononuclear cells instead of isolated B cells in the expression studies is a limitation of the study. In addition, the determination of intracellular cytokine levels in addition to surface markers during immunophenotyping could contribute to a better understanding of the immunological mechanisms.

In conclusion, it was shown that anti-inflammatory B cells were increased, the levels of genes supporting B cell development were decreased, and B cell suppressed genes were increased in a group of MS patients with close clinical and demographic characteristics. These findings support the view that B cell functions may have molecular and cellular effects, and may lead to regression in inflammation and clinical progression. In addition, it is possible that molecules showing significant changes in our study may play a role as prognostic biomarkers in MS. In future studies, validation of the value of BLK, TGFB, BANK, KCNS, FCRL and BLNK gene expressions in isolated peripheral $B$ cells as a biomarker to determine the effect of $B$ cells in the pathogenesis of MS is planned in a wider patient population.

Ethics Committee Approval: Ethics committee approval was received for this study from the Clinical Research Ethics Committee of İstanbul University School of Medicine (2018/449).

Informed Consent: Written informed consent was obtained from the parents' of the patients who participated in this study.

Peer-review: Externally peer-reviewed.

Author Contributions: Concept - T.I., I.Y.; Supervision - T.I., I.Y; Materials - H.E., H.S.; Data Collection and/or Processing - B.T.H.,M.T.H., C.H.; Analysis and/or Interpretation - C.H., I.Y., A.E., Ü.Z.; Literature Search - B.T.H., D.S. M.T.H.,; Writing - B.T.H., C.H.; Critical Reviews - H.S., I.Y., B.T.H.

Conflict of Interest: The authors have no conflict of interest to declare.

Financial Disclosure: This study was funded by Scientific Research Projects Coordination Unit of İstanbul University (Project number 30793).

Etik Komite Onayı: Bu çalışma için etik komite onayı İstanbul Üniversitesi Tıp Fakültesi Klinik araştırmalar Etik Komitesinden alınmıştır (2018/449).
Hasta Onamı: Yazılı hasta onamı bu çalışmaya katılan hastaların ebeveynlerinden alınmıştır.

Hakem Değerlendirmesi: Dış bağımsız.

Yazar Katkıları: Fikir - T.I., I.Y.; Denetleme - T.I., I.Y.; Gereçler - H.E., H.S.; Veri Toplanması ve/veya İşlemesi - B.T.H., M.T.H., C.H.; Analiz ve/veya Yorum - C.H., I.Y., A.E., Ü.Z.; Literatür Taraması - B.T.H., D.S. M.T.H.; Yazan - B.T.H., C.H.; Eleştirel Inceleme - H.S., I.Y., B.T.H.

Çıkar Çatışması: Yazarlar çıkar çatışması bildirmemişlerdir.

Finansal Destek: Bu çalışma İstanbul Üniversitesi Bilimsel Araştırma Projeleri Koordinasyon Birimi tarafından desteklenmiştir (Proje No:30793).

\section{REFERENCES}

1. Garg N, Smith TW. An update on immunopathogenesis, diagnosis and treatment of multiple sclerosis. Brain Behav 2015; 5: 1-13. [CrossRef]

2. Samkoff LM, Goodman AD. Multiple Sclerosis and CNS Inflammatory Disorders,Wiley-Blackwell; 2014. [CrossRef]

3. Lublin FD, Reingold SC. Defining the clinical course of multiple sclerosis: Results of an international survey. Neurology 1996; 46: 907-11. [CrossRef]

4. Hawkins SA, McDonell GV. Benign multiple sclerosis? Clinical course, long term follow up, and assessment of prognostic factors. J Neurol Neurosurg Psychiatry 1999; 67: 148-52. [CrossRef]

5. Ozakbas S, Turkoglu R, Tamam Y, Terzi M, Taskapilioglu O, Yucesan $C$, et al N. Prevalence of and risk factors for cognitive impairment in patients with relapsing-remitting multiple sclerosis: Multi-center, controlled trial. Mult Scler Relat Disord 2018; 22: 70-6. [CrossRef]

6. Tuzun E. Multipl skleroz patogenezinde $B$ hücrelerinin rolü ve $B$ hücre karşıtı monoklonal antikor tedavileri. Nöropsikiyatri Arşivi 2011; 48: 73-8. [CrossRef]

7. Sospedra M, Martin R. Immunology of multiple sclerosis. Annu Rev Immunol 2005; 23: 683-747. [CrossRef]

8. Naegelin $Y$, Naegelin P, von Felten S, Lorscheider J, Sonder J, Uitdehaag BMJ, et al. Association of Rituximab Treatment With Disability Progression Among Patients With Secondary Progressive Multiple Sclerosis JAMA Neurol 2019; 76: 274-81. [CrossRef]

9. Yamout BI, El-Ayoubi NK, Nicolas J, El Kouzi Y, Khoury SJ, Zeineddine MM.Safety and Efficacy of Rituximab in Multiple Sclerosis: A Retrospective Observational Study. J Immunol Res 2018; 2018: doi: 10.1155/2018/9084759. [CrossRef]

10. Achiron A, Feldman A, Magalashvili D, Dolev M, Gurevich M. Suppressed RNA-polymerase 1 pathway is associated with benign multiple sclerosis. PLoS One 2012; 7: doi: 10.1371/journal. pone.0046871. [CrossRef]

11. Yang J, Ren J, Yang Y, Sun J, Zhou X, Zheng S, et al. BANK1 alters B cell responses and influences the interactions between $B$ cells and induced $T$ regulatory cells in mice with collagen-induced arthritis. Arthritis Res Ther 2018; 20: 9. doi: 10.1186/s13075-017-1503-x. [CrossRef]

12. Kurtzke, J.F., A reassessment of the distribution of multiple sclerosis. Acta Neurologica Scandinavica 1975; 51: 110-36. [CrossRef]

13. Willer $C J$, Dyment DA, Sadovnick AD, Ebers GC. Maternal-offspring HLA-DRB1 compatibility in multiple sclerosis. Tissue Antigens 2005; 66: 44-7. [CrossRef]

14. DüzgünN.İmmünSisteminTanıtımı.s:97-122.Availablefrom:URL:http:// ichastaliklariromatoloji.medicine.ankara.edu.tr/files/2014/02/\%C4\%B0mm\%C3\%BCn-Sistemin-Tan\%C4\%B1t\%C4\%B1m\%C4\%B1.pdf 
15. O'Connor BP, Raman VS, Erickson LD, Cook WJ, Weaver LK, Ahonen $C$, et al. BCMA is essential for the survival of long-lived bone marrow plasma cells. J Exp Med 2004; 199: 91-8. [CrossRef]

16. Aktura ŞD, Yılmaz V, Özkan-Yaşargün D, Ulusoy C, Tüzün E, Türkoğlu R. Peripheral blood memory B cell frequency predicts conversion from clinically isolated syndrome to multiple sclerosis. Mult Scler Relat Disord 2018; 23: 9-14. [CrossRef]
17. Komai $T$, Inoue $M$, Okamura $T$, Morita $K$, Iwasaki $Y$, Sumitomo $S$, et al. Transforming growth factor- $\beta$ and interleukin-10 synergistically regulate humoral immunity via modulating metabolic signals. Front Immunol 2018; 9: 1364. doi: 10.3389/fimmu.2018.01364. [CrossRef]

18. Molnarfi N, Bjarnadóttir K, Benkhoucha M, Juillard C, Lalive PH. Activation of human $B$ cells negatively regulates TGF- $\beta 1$ production. J Neuroinflammation 2017; 14: 13. doi: 10.1186/s12974-017-0798-5. [CrossRef] 